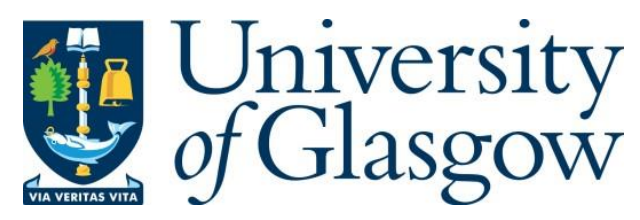

Lamont, C. (2021) Stewart \& Meikle's The Poetical Miscellany (1800): a problematic Glasgow ‘edition' of Robert Burns. Burns Chronicle, 130(1), pp. 59-70.

There may be differences between this version and the published version. You are advised to consult the publisher's version if you wish to cite from it.

http://eprints.gla.ac.uk/252475/

Deposited on: 22 September 2021

Enlighten - Research publications by members of the University of Glasgow http://eprints.gla.ac.uk 


\title{
STEWART \& MEIKLE'S THE POETICAL MISCELLANY (1800): A PROBLEMATIC GLASGOW 'EDITION' OF ROBERT BURNS
}

\author{
Craig Lamont
}

In the landscape of Robert Burns's bibliography it is well known that the title of his debut edition, Poems, Chiefly in the Scottish Dialect (Kilmarnock: 1786), was reused for subsequent iterations of his work well beyond his death. New editions bearing this title appeared regularly throughout Britain and North America until around 1824. For all this marketing opportunism in Burns's lifetime and beyond, no Glasgow publisher had put together a comprehensive edition of poems until Thomas Stewart's Poems Ascribed to Robert Burns, the Ayrshire Bard appeared in 1801. In the same year Thomas Duncan and the partners Chapman and Lang each published their own Glasgow editions under that original title Poems, Chiefly in the Scottish Dialect. But the story of Burns's works printed in Glasgow is better told in looking at the spate of chapbooks that were printed and sold cheaply, in the 1790 and early $1800{ }^{1}{ }^{1}$

The best known collection is Brash and Reid's Poetry; Original and Selected, appearing in four volumes of 24 pamphlets each, including works by many hands. Of the 96 total numbers, 18 of them contain Burns material. ${ }^{2}$ In Egerer's bibliographical survey he declares these pamphlets as scarce but essential for any good Glasgow library. ${ }^{3}$ According to Iain Beavan this collection was produced by Robert Chapman, of the same Chapman and Lang, above, who printed Burns's poems in $1801 .{ }^{4}$ While most of the pamphlets bear the same colophon 'Glasgow: Printed for and Sold by Brash \& Reid' - the names Chapman and Lang do appear on a variant issue of Alloway Kirk; or Tam O' Shanter. A Tale. (1796). ${ }^{5}$ The scope of these variants was laid out by G. Ross Roy in 1989 with illustrations showing the different rules, designs, and, in one case, the misspelling of 'Alloway' as 'Aloway'. ${ }^{6}$ Another copy with the 'Aloway' title-page was since acquired by the Roy Collection at the University of South Carolina.

It is another collection which is the focus of this essay. In 1796 the partners Stewart and Meikle commenced the publication of what would become a total of eight chapbooks, beginning with An Unco Mournfu Tale [1]. One half of this partnership was the same Thomas Stewart who went on to publish Poems Ascribed to Robert Burns (1801) and the controversial Letters Addressed to Clarinda (1802). After a few years the names Stewart and Meikle became synonymous with Burns chapbooks, and on 13 July 1799 they published The Jolly Beggars: $a$ Cantata [2]. This was the first instance of Burns's famous tale in print, though it lacked the 'Merry Andrew' episode, first printed in Duncan's edition of Poems, Chiefly in the Scottish Dialect (Glasgow: 1801). ${ }^{7}$ Thereafter, for each of the following six weeks until 7 September, they published The Kirk's Alarm [3], Holy Willie's Prayer [4], Extempore Verses on Dining with Lord Daer [5], The Inventory [6], The Henpeck'd Huband [7], and The Passage of Mount St. Gothard

\footnotetext{
${ }^{1}$ The main findings of this essay were fed into the present author's Bibliography of Robert Burns for the $21^{\text {st }}$ Century: 1786-1802 (Glasgow: Centre for Robert Burns Studies, 2017; 2018):

https://www.gla.ac.uk/media/Media_518307_smxx.pdf. The study was conducted under the auspices of the AHRC-funded project 'Editing Robert Burns for the $21^{\text {st }}$ Century' (PI: Prof Gerard Carruthers).

${ }^{2} \mathrm{~J}$. C. Ewing, Brash and Reid: Booksellers in Glasgow, and their collection of Poetry, Original and Selected (Glasgow: Robert Maclehose, 1934), and in Records of the Glasgow Bibliographical Society, 21 (1936): 1-20.

${ }^{3} \mathrm{~J}$. W. Egerer, A Bibliography of Robert Burns (Edinburgh \& London: Oliver \& Boyd, 1964), 55.

${ }^{4}$ Iain Beavan, 'The Decline and Fall of the Scottish Chapbook', Street Literature of the Long Nineteenth Century: Producers, Sellers, Consumers eds. David Atkinson and Steven Roud (Newcastle: Cambridge Scholars Publishing, 2017), 154-93 (171-2).

${ }^{5}$ Elizabeth Sudduth, The G. Ross Roy Collection of Robert Burns: An Illustrated Catalogue (Columbia, SC: The University of South Carolina Press, 2009), 31.

${ }^{6}$ G. Ross Roy, 'The Brash and Reid Editions of “Tam o' Shanter"', Burns Chronicle 1989, 38-44.

${ }^{7}$ Egerer, 85; cf. pp. 251-61 of Duncan's 1801 edition.
} 
[8], each containing some original Burns material. Then, in 180o, a new 'edition' of Burns poems titled The Poetical Miscellany was published in Glasgow. A note 'To the Public' was bound inside:

The Editors beg leave to present the Public with a small volume, which they have spared neither trouble nor expence to render worthy of acceptance.

Of the merit of this MISCELLANY, nothing more need be said, than that it chiefly consists of posthumous pieces, by Robert Burns, the justly celebrated Ayrshire bard; whose memory will be cherished, while the efforts of vigorous genius, and the simple graces of nature, are objects of admiration. A number of these pieces were never published before, and in every one of them, the peculiar manner of the author will be readily recognized by his admirers.

Among the original productions of Burns, the editors cannot avoid a particular notice of the JOLLY BEGGARS, which, of itself, is sufficient to give celebrity to any collection. The pleasing variety of recitative and songs, affording specimens of almost every measure of verse; the appropriate humour of the respective characters; the natural description of the manners and enjoyments of "the wandering train;" and the simplicity of the ancient Scottish dialect which it displays, rank it among the foremost sallies of our favourite Poet.

To those who may object to any appearance of unguarded levity in some of these productions of Burns, the Editors must plead the extreme avidity with which every relic of him is sought after; and the numerous solicitations which they have received to publish the pieces alluded to, "with all their imperfections on their head."

There are also, in the following Miscellany, a few original productions, by gentlemen of this city, which, it is hoped, will be found to possess merit sufficient to excite a wish, that our young gentlemen would more frequently employ their talents in the cultivation of such a pleasing and elegant art.

This clever, detailed editorial note helps centralise Burns's print legacy in Glasgow, rather than Edinburgh or London, while treating any morally questionable material as mere remnants of a distant age (four short years after his death). The Contents pages (pp. [3]-4) tellingly lack any page number references, but rather list seven items contained within, as follows [only the first title in each number is shown]:
No. 1 | Jolly Beggars
No. 2 The Kirk's Alarm
No. 3 | Holy Willie's Prayer
No. 4 | Extempore Verses on Dining with Lord Daer
No. 5 | The Inventory
No. 6 | Henpeck'd Husband
No. 7 | The Passage of Mount St. Gothard

To put it simply, The Poetical Miscellany is made up of the seven chapbooks published by Stewart and Meikle in 1799, omitting the Unco Mournfu Tale published in 1796. It makes complete sense that once each of these seven chapbooks were in circulation, they would simply gather them under a new title and sell them together. As Sandro Jung has shown, the frontispiece for The Poetical Miscellany, showing a satyr and nymph crowning a portrait of Burns with a wreath of bays, is strikingly similar to the frontispiece used in Stewart and Meikle's Poems 
of Allan Ramsay (1797). ${ }^{8}$ As it happens, Ramsay serves as an excellent example of an earlier bibliographical case study not unlike Burns's Poetical Miscellany.

Allan Ramsay's Poems (1721) were printed in Edinburgh by Thomas Ruddiman (16741757). This edition consisted of around 380 pages-worth of poems and songs, many of which had been in circulation in chapbooks and broadsides for some years. However, many libraries hold a 1720 'edition' of Ramsay's Poems, bearing a seemingly authentic title-page and the same printing devices and decorations used by Ruddiman in the 1721 edition. Beyond the 1720 titlepage, however, the book is comprised of recycled title-pages for individual works previously, or in some cases subsequently, printed..$^{9}$ This 1720 Ramsay also varies from copy to copy, less an edition than it is a Frankenstein of other chapbooks. The intended order is there, but its bibliographical makeup is worthy of another study entirely.

Stewart and Meikle's Poetical Miscellany is a similar, if less extreme, case. First of all there is no hiding the very recent history of their chapbooks. In the Contents page they note that 'Any of the above Numbers may be had separately at $2 \mathrm{~d}$. each.' However, reading this specific note is dependent on which copy is consulted. Both the National Library of Scotland (NLS) and the Robert Burns Birthplace Museum (RBBM) copies carry this note, and an engraving of two doves below it. The copy held at the University of British Columbia (UBC), however, reads [emphasis added]: 'Any of the above Numbers may be had separately at $2 \mathrm{~d}$. each; and the whole stitched, price 1s.' This is not the only variant in the title-page. No. 1 in both the NLS and RBBM copies is listed as: 'The Jolly Beggars, a Cantata, by Burns.' But in the UBC copy three more items are listed as part of No. 1: 'Lines of Wrangling'; 'The Gentleman's Wish'; 'The Lady's Choice.' And so it goes, as follows, throughout the rest of the Contents list [full titles shortened]:

$\mathrm{NLS}^{10} \& \mathrm{RBBM}^{11}$

No. 2 The Kirk's Alarm

Poetical Letter to a Taylor

Epitaph on John Dow

De'il's awa wi' the Exciseman

The Twa Herds, an unco mournfu' tale

No. 3 Holy Willie's Prayer

Poetical Letter to John Gowdie

Duncan Gray

A Man's a Man for a' that

Now westlin' winds

I gaed a waefu' gate yestreen

\section{$\mathrm{UBC}^{12}$}

The Kirk's Alarm

Epistle from a Taylor

Epitaph on John Dove

De'il's awa wi' the Exciseman

The Holy Toolzie: an unco mournfu' Tale

Holy Willie's Epitaph

Holy Willie's Prayer

Letter to John Gowdie

Duncan Gray

A Man's a Man for a' that

Now westlin' winds

I gaed a waefu' gate yestreen

Two Epigrams

\footnotetext{
${ }^{8}$ Sandro Jung, The Publishing and Marketing of Illustrated Literature in Scotland, 1760-1825 (Bethlehem: Lehigh University Press, 2018), 113-4. Cf. Sandro Jung, 'The Glasgow Poetry Chapbook, 1796-1799: Brash and Reid's 'Small Selections', Cameron and Murdoch's 'most celebrated Pieces, both Scots and English', Murdoch's The Polyhymnia and the Stewart and Meikle Burns Chapbooks', Journal of the Edinburgh Bibliographical Society (2017): 87-107.

${ }^{9}$ The NLS Glen 106 copy bears the title-page (Edinburgh: 1720), but, rather than being a single issue, in fact contains The Morning Interview (1721); Tartana (1721); and even a 1722 Chris's-Kirk on the Green.

${ }^{10}$ NLS F.7.f.31(1)

${ }^{11}$ RBBM 3.313

${ }^{12}$ UBC PR4303 .A3 1800
} 
No. 4 Extempore Verses [...] Lord Daer

Dominie Depos'd, part first, by W. Forbes

No. 5 The Inventory, a letter to R-A-

Dominie Depos'd, part second, by W. Forbes

Lines on the Palace of Scone

The Comforts of Matrimony

Plundered Lark

Address to a Lily

No. 6 Henpeck'd Husband

Address to his Illegitimate Child

Epigram

Epigram, on [...] death of Thomas Paine

Kissing

Dancing

Stanzas to [...] Burns, by Edward Rushton

Humanity's Power

The Wounded Hussar, by T. Campbell

The Galley Slave

The Sailor's Journal

Willy and Nelly

No. 7 The Passage [...] by Dutchess of Devonshire

The Chevalier's Lament

The Lass of Gowrie

Shelah O'Neil

Last May a braw wooer

Epitaph on a Wag in Mauchline

An original Song [...] Cowl Club, Glasgow

Corin's Profession, by Peter Pindar
Extempore Verses [...] Lord Daer

Dominie Depos'd, part first, by W. Forbes

The Inventory, a letter to $\mathrm{R}-\mathrm{A}-$

Lines on the Palace of Scone

Dominie Depos'd, part second, by W. Forbes

The Comforts of Matrimony

Plundered Lark

Address to a Lily

Henpeck'd Husband

Address to his Illegitimate Child

Epigram

Epigram, on [...] death of Thomas Paine

Kissing

Dancing

Stanzas to [...] Burns, by Edward Rushton

Humanity's Power

The Wounded Hussar, by T. Campbell

The Galley Slave

The Sailor's Journal

Willy and Nelly

The Passage [...] by Dutchess of Devonshire

The Chevalier's Lament

Last May a braw wooer

Song on Miss Peggy K-

The banks of the Devon

Epitaph on a Wag in Mauchline

The Lass of Gowrie

Shelah O'Neil

An original Song [...] Cowl Club, Glasgow

Corin's Profession, by Peter Pindar

At the moment, this would indicate that there were at least two separate printings of the prelims for The Poetical Miscellany, suggesting that there were at least two separate issues in that form, or perhaps even that the collected form of the chapbooks were done as needed over a period of time, not as a single publication event or events. As this essay will go on to show, however, there are many more minutiae to consider which ultimately makes it difficult to treat the work as an 'edition' at all. In his Bibliography Egerer acknowledges that The Poetical Miscellany is the form in which [the seven chapbooks of 1799 ] were gathered and reissued. It does not agree with the collations of the original issues, and evidently was reset and reprinted. ${ }^{13}$ The misleading description here is 'original issues.' On first reading the statement is obvious enough: some of the individual works in The Poetical Miscellany vary from their first setting because they were reset for this new collected edition. But in going back over Egerer's description of those 'original issues' the situation becomes even more confusing. Number 5, The Inventory, is described as having a variant title page. In the 'original', the colophon reads 'Glasgow, | Printed by Chapman and Lang, | for STEWART \& MEIKLE.' while the variant reads 'Glasgow, | Printed by Chapman and Lang, Trongate, | for STEWART \& MEIKLE." ${ }^{\prime 4}$ None of the other six chapbooks of 1799 are noted as having a variant title-page by Egerer, but readers will assume that there must be more than one if The Poetical Miscellany is alleged to have been 'reset and reprinted.' And indeed

\footnotetext{
${ }^{13}$ Egerer, 68.

${ }^{14}$ Egerer, 63.
} 
there are. Collating these was never Egerer's aim, but in describing the first instance of each number as 'original issues' implies that they were reset once (except for The Inventory) for The Poetical Miscellany. This in turn gives it credence as a functioning edition, which it is not. Indeed, we need to turn back to the separate editions and track just how many variants there are. Only then, with that knowledge, can we determine the true nature of The Poetical Miscellany.

In the case of The Jolly Beggars: a Cantata, there are at least three variant issues. There are also at least three variant issues of The Kirk's Alarm, and at least two variant issues of Holy Willie's Prayer, ${ }^{15}$ Extempore Verses on Dining with Lord Daer, and The Inventory. This last is the only Stewart \& Meikle chapbooks for which Egerer notes a variant title-page, outside the variant versions of The Poetical Miscellany. Before we look into the tell-tale variants in detail it is worth illustrating the four chief engravings that help identify similarly titled copies across these seven numbers [Fig. 1].
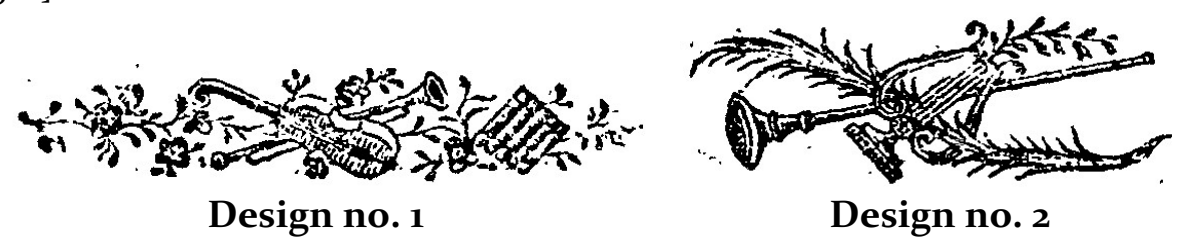

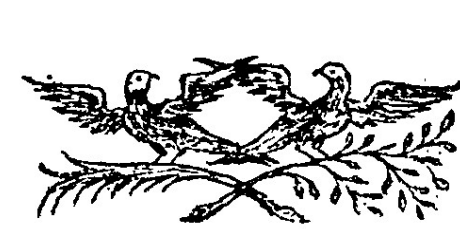

Design no. 3

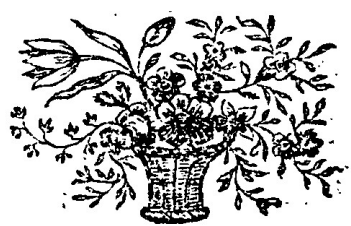

Design no. 4

Fig. 1. Decorative designs printed in the Stewart and Meikle chapbooks.

The following five tables show the exact variants used to identify separate printings. For each chapbook, the variant printings so far identified are assigned letters (a), (b), or (c); for convenience, the headnote for each item indicates the copies examined matching each printing. As there are not many complete copies of The Poetical Miscellany extant, many of the copies are held individually, or as part of other chapbook collections. Where an asterisk appears beside a shelfmark it is to indicate that that copy is bound as part of The Poetical Miscellany.

\author{
Key for shelfmarks: \\ BL British Library \\ GU University of Glasgow Library \\ NLS National Library of Scotland \\ RBBM Robert Burns Birthplace Museum \\ UBC University of British Columbia \\ USC University of South Carolina
}

\footnotetext{
${ }^{15}$ Not to be confused with the two chapbooks titled The Prayer of Holy Willie, first in Kilmarnock by John Wilson (printer of Burns's debut collection, 1789) and secondly in Edinburgh in 1799, this time with Burns's name on the title-page.
} 
Table 1. Variants across three issues of The Jolly Beggars (Egerer 39).

Variant [a]: USC RBSC Rare PR .4311 .A1 1799 S.L (3); NLS RB.s.445. Variant [b]: GU Sp. Col. Bh12-f.42 (1); NLS F.7.f.31(1)*; UBC PR4303 .A3 1800*. Variant [c]: BL RB.23.a.10129*; NLS L.C. 2398 (36); ML 311291; ML 52713*; RBBM 3.313*.

Title-page text

[a] The Jolly Beggars: A Cantata.

[b, c] The Jolly Beggars; or, Tatterdemallions.

A Cantata.

p. 2

Title-page illustration

[a] blank

[b, c] 'The Jolly Beggars: A Cantata.'

[a] Design 1
[b] Design 2
[c] Design 1

p. $14^{16}$

[a] n/a

[b] Design 3

[c] Design 4

Title-page colophon

[a] Printed for and Sold by Stewart \& Meikle

p. 16

[b] Printed by Chapman and Lang, For

[a] Advertisement

Stewart \& Meikle

[b] 'The Gentleman's Wish'

[c] Printed by Chapman \& Lang, Trongate For

[c] 'The Wish'

Stewart \& Meikle

Table 2. Variants across three issues of The Kirk's Alarm (Egerer 40).

Variant [a]: RBBM 3.313*; USC RBSC Rare PR 4311 .A1 1799 S.L. (2); NLS RB.s.445 (3); USC

RBSC Rare PR 4312 .K5 1799 S.L. Variant [b]: GU Sp. Col. Bh12-f.42 (2); UBC PR4303 .A3 1801; ML52713*; UBC PR4303 .A3 1800*; Variant [c]: NLS L.C. 2398 (38); NLS F.7.f.31(1)*; BL

RB.23.a.10129*.

\section{Colophon}

[a] Printed for and Sold by Stewart \& Meikle

[b] Printed by Chapman and Lang, For

Thomas Stewart, Bookseller and Stationer.

[c] Printed by Chapman \& Lang, For Stewart \& Meikle

p. 5

[a] decorative rule

[b] double rule

[c] decorative rule

p. 10

[a] decorative rule

[b] double rule [c] diamond rule

p. 12

[a] diamond rule | 'An Unco Mournfu' Tale.'

[b] double rule |'The Holy Toolzie: An Unco Mournfu' Tale.'

[c] decorative rule | 'An Unco Mournfu' Tale.'

p. 16

[a] Advertisement for The Jolly Beggars and

Holy Willy's [sic] Prayer

[b] 'Epitaph on Holy Willie' | Advertisement for Poems, Ascribed to Robert Burns

[c] Advertisement for 'Posthumous Pieces by Robert Burns'

Table 3. Variants across two issues of Holy Willie's Prayer (Egerer 41).

Variant [a]: USC RBSC Rare PR 4311 .A1 1799 S.L. (1); BL RB.23.a.10129*; ML 311293; RBBM

3.313*. Variant [b]: GU Sp. Col. Bh12-f.42 (3); UBC PR4303 .A3 180oa; NLS F.7.f.31(1)* [6]; NLS

L.C. 2398 (37); ML 52713*; UBC PR4303 .A3 1800*

Title-page illustration

\footnotetext{
${ }^{16}$ Confusingly, the NLS copy of The Poetical Miscellany, shelfmark F.7.f.31(1), contains a pasted engraving from an unidentified source over the two doves, ie. Design 3 (which can nonetheless be seen when the leaf is held against light).
}

[a] Design 2 
[b] Design 3

\section{Title-page colophon}

[a] Printed for and Sold by Stewart \& Meikle.

[b] Printed by Chapman and Lang, For

Stewart \& Meikle.

p. 12 [a] decorative rule

[b] double rule

p. 16

[a] decorative rule | Advertisement for previous and upcoming issues

[b] diamond rule | 'The Rake'

Table 4. Variants across two issues of Extempore Verses on Dining with Lord Daer

(Egerer 42). Variant [a] GU Sp. Col. Bh12-f.42(4); NLS L.C. 2398 (39); UBC PR4303 .A3 1799a V. 5; BL RB.23.a.10129*; NLS L.C. 2398(39); ML 311294; ML 52713*; RBBM 3.313*; UBC PR4303 .A3 1800*. Variant [b]: NLS F.7.f.31(1)*.

\section{Title-page illustration}
[a] Design 2
[b] Design 1

\section{Title-page colophon}

[a] Printed for and Sold by Stewart \& Meikle.

[b] Printed by Chapman and Lang, For Stewart \& Meikle.

p. 16

[a] diamond rule | Advertisement for Part II of The Dominie Depos'd

[b] 'finis' scroll vignette

Table 5. Variants across two issues of The Inventory (Egerer 43).

Variant [a]: BL RB.23.a.10129*; GU Sp. Col. Bh12-f.42 (5); ML 52713*; RBBM 3.313*; USC RBSC Rare PR 4310 .I5 S.L.; UBC PR4303 .A3 1800*. Variant [b]: NLS L.C. 2398 (40); NLS F.7.f.31(1)*; UBC PR4303 .A3 1799a V. 6; ML 311292.

\section{Colophon}

[a] Printed by Chapman and Lang, Trongate, For Stewart \& Meikle.

[b] Printed by Chapman and Lang, For Stewart \& Meikle.

\section{'The Dominie Depos'd'}
[a] begins at p. 2
[b] begins at p. 6

\section{'The Inventory'}
[a] begins at p. 8

[b] begins at p. 2

\section{p. 2}

[a] 'The Dominie Depos'd'

[b] 'The Inventory'

\section{p. $10[a] /$ p. 4 [b]}

[a] 'Lines Written with a pencil on the Wall of one of the Apartments of the Palace of Scone, July 1799.'

[b] Lines Written with a pencil on the Wall of one of the Apartments of the Palace of Scone, July 1799, By a Gentleman of Glasgow.'

p. 11

[a] Design 2

[b] Design 4

p. 16

[a] Advertisement for previous issues

[b] No advertisement 
There are no extant variant issues of numbers 6 (The Henpeck'd Husband) or 7 (The Passage of Mount St. Gothard), meaning that either they were printed only once, or that variant issues are simply lost. The first scenario makes sense theoretically, because it is reasonable to assume that by the time Stewart and Meikle had commenced printing these last two numbers they had begun planning for The Poetical Miscellany, and so had them printed to suit that volume without the need to reset them. But the only evidence that this may be the case is the lack of a variant issue for either, which may yet turn up. There is, however, one last problem in this assumption. Going back to the Contents pages, above, we see that both lists for The Henpeck'd Husband are identical, giving weight to the theory that the publishers had finally settled on the idea of gathering up the chapbooks as one. However, neither list conforms to the actual contents of The Passage of Mount St. Gothard, as Table 6 shows:

Table 6. Tabulated contents lists (first two columns) of the two variant Contents pages set for The Poetical Miscellany and (in the third column) the contents of The Passage of Mount St. Gothard as they appear.

\section{Variant 1 (NLS F. 7.f.31(1)/ \\ RBBM 3.313)}

The Passage of Mount St.

Gothard;

The Chevalier's Lament;

The Lass of Gowrie;

Shelah O'Neil;

Last May a braw wooer;

Epitaph on a Wage in

Mauchline;

An original Song;

Corin's Profession;

\author{
Variant 2 \\ (UBC PR4303 .A3 180o) \\ The Passage of Mount St. \\ Gothard; \\ The Chevalier's Lament; \\ Last May a braw wooer; \\ Song on Miss Peggy K-; \\ The banks of Devon; \\ Epitaph on a Wag in Mauchline; \\ The Lass of Gowrie; \\ Shelah O'Neil; \\ An original Song; \\ Corin's Profession;
}

\author{
Contents of the edition \\ The Passage of Mount St. \\ Gothard (p. 2) \\ The Chevalier's Lament (p. 7) \\ The Lass of Gowrie (p. 8) \\ Song on Miss Peggy K- (p. 9) \\ Shelah O'Neil (p. 11) \\ Last May a braw wooer (p. 12) \\ Epitaph on a Wag in Mauchline \\ (p. 13) \\ An original Song (p. 14) \\ Corin's Profession (p. 15) \\ The banks of Devon (p. 16)
}

Given that neither printed list describes accurately the contents of that chapbook, or at least the extant copies we have, we are forced to ponder once more the possibility of lost variant issues. That both listings for The Henpeck'd Husband are identical, above, offers the alternate possibility that these printed lists for The Passage of Mount St. Gothard were simply erroneous. This is more likely, as, after all, the listings for the other issues do not line up exactly.

Firstly, two of these seven chapbooks were set three times. Second, neither contents list for The Inventory matches either of the variant issues. And finally, the titles given in the contents list often differ from the titles previously printed. For instance, one contents list prints 'John Dow', the other 'Dove', and, more tellingly, one list prints the title 'The Twa Herds' and the other 'The Holy Toolzie'. If we look at Table 2, page 12, it reveals that none of the three variants actually carry the title 'The Twa Herds.' We do find this alternate title for 'The Holy Toolzie' in several other editions of Burns in 1801, including Thomas Stewart's Poems Ascribed to Robert Burns, the opening 60 or so pages of which actually comprise the material across his chapbook series with Meikle. In other words, both contents lists are unstable and unreliable afterthoughts, tacked on to a series of gathered chapbooks and sold as a new collected work.

None of the copies of The Poetical Miscellany available for this study have proved to be identical. We should therefore begin to treat the contents of it, ie. the individual, gathered 
chapbooks as extant copies that were printed individually. These seven chapbooks are (small) editions in their own right. The Poetical Miscellany, on the other hand, is not. While there is no evidence to suggest it should be referred to as an 'edition' it is nonetheless helpful that libraries and collectors continue to treat the title based on its intended use. Traditional accounts of the unauthorized Glasgow editions in which much of Burns's reserved canon first reached print greatly oversimplify the bibliographical complexity of their printing history. Neglecting this complexity, and ignoring how often a given chapbook had to be reprinted in a relatively short period, shortchanges popular enthusiasm for Burns, especially in Glasgow and the West of Scotland, and underplays the rapidity with which, after Burns's death, poems came into circulation that his trustees, editor, and publishers excluded from the authorized editions for years to come. 